This work is licensed under a Creative Commons Attribution 4.0 International License.

Ovaj rad dostupan je za upotrebu pod međunarodnom licencom Creative Commons Attribution 4.0.

https://doi.org/10.31820/f.30.2.12

Karlo Jurak

\title{
PROBLEM KONSTITUCIJE GOVOREĆEG SUBJEKTA I MOGUĆNOST METALINGVISTIKE
}

Karlo Jurak, mag. phil. et ling., Arhiv Srba u Hrvatskoj, karlojurak@gmail.com, Zagreb

pregledni članak

UDK 81'1

rukopis primljen: 27. 2. 2018.; prihvaćen za tisak: 16. 11. 2018.

Problem odnosa između jezične strukture i govorećeg subjekta zahvaća skoro svaku lingvističku teoriju još i prije Ferdinanda de Saussurea koji je tu dihotomiju razvio do krajnjih konzekvenci u utemeljenju strukturalizma kao znanstvene paradigme. Tu centralnu dihotomiju prate i druge poput one izmedu funkcije $i$ forme te primata jezika ili mišljenja. Razmatrajući tako lingvističke teorije prije i poslije Saussurea možemo vidjeti da je svugdje barem implicitno prisutan ovaj problem. Kako bi se taj problem nadišao, u ovom se radu konstituciji govorećeg subjekta prilazi mimo ustaljenih dihotomija koristeći koncepte jezičnog upravljanja, metajezika te metajezične sposobnosti. Usto dolaze pretpostavke o svjesnosti jezične djelatnosti, njezinu inherentno metajezičnom karakteru te mogućnosti konstituiranja subjektivnosti samoga govornoga aktera pomoću refleksivnosti i dijalogičnosti. U tu svrhu govoreći se subjekt provlači kroz tri dimenzije sa svojim specifičnim problemima - kroz filozofsku, političku i pragmatičku dimenziju. Glavna je značajka filozofske dimenzije ontološko i epistemološko utemeljenje jezičnoga fenomena te odnos jezika i mišljenja; kod političke dimenzije riječ je o pitanjima moći i hegemonije; na pragmatičkoj se razini ističe raspad dihotomije izmedu deskriptivnosti i performativnosti kao različitih jezičnih funkcija. Konačno, cilj je rada na navedenim pretpostavkama afirmirati metalingvistiku univerzalnoga karaktera ostajući u imanentnim okvirima, tj. u okvirima samoga jezika.

Ključne riječi: govoreći subjekt; jezična struktura; jezično upravljanje; metajezik; metajezična sposobnost; metalingvistika 


\section{Uvod u problem. Lingvističke teorije i govoreći subjekt}

Jezik nije funkcija govorećeg subjekta. ${ }^{1}$

S Ferdinandom de Saussureom lingvistička je misao konačno dobila svoj zaokruženi znanstveni oblik, tj. od pojave njegova Tečaja opće lingvistike (dalje: Tečaj) govori se o modernoj općoj lingvistici. Jezik je postavljen kao predmet znanstvene discipline per se i in se, ali na način da nije već unaprijed dan kao gotova masa (matiére) na koju treba primijeniti znanstvenu metodu, već da je sâm jezik kao spoznati predmet cilj (svrha, telós) do kojega treba doći znanošću:

„Za Saussurea matiére skup je svih pojava koje se, na razini svakodnevnog jezika, mogu smatrati 'jezičnima'. Ta je masa nepravilna i, kao takvu, mogu je izučavati raznovrsne discipline, a u odnosu prema njima lingvistika se određuje time što je njezin predmet (objet) jezik (langue)... Potonji termin Saussure ovdje rabi u smislu 'cilja neke djelatnosti, čina', tj. u skolastičkom smislu gdje je obiectum jedne znanosti sadržaj znanja u mjeri u kojoj je naučen i spoznat" (Mauro 2000: 453-453).

Na razini apstrakcije koju uvodi Saussure razvijaju se dihotomije koje inauguriraju temeljni problem lingvističkih teorija - odnos između strukture i subjekta. Taj problem, koji se s pravom može okarakterizirati kao jedan od najvećih teorijskih problema 20. stoljeća, prisutan je u mnogim lingvističkim teorijama i prije i poslije Saussurea, no tek ih Saussureova razina apstrakcije uvodi u svojoj punini. Konkretno, u slučaju lingvistike, govori se o odnosu između jezične strukture i govorećeg subjekta, slijedeći Saussureovu dihotomiju jezika (langue) i govora (parole) koja je i mnogo prije njega implicitno prisutna u lingvističkim teorijama. Prema tome, na osnovi te dihotomije postavlja nam se pitanje kako razviti zaokruženu i nekontradiktornu teoriju jezične djelatnosti (langage)?²

1 Riječ je o parafrazi temeljne misli Saussureova Tečaja opće lingvistike i lingvističkog strukturalizma općenito, što će imati svoje dalekosežne odjeke i u drugim društvenim i humanističkim disciplinama (Saussure 2000).

2 Pod „nekontradiktornom teorijom” podrazumijeva se ona teorija koja će uspjeti nadići suprotnosti kojima je Saussureov Tečaj bremenit. Dakle, u ovom je radu jedna od početnih 
Stoga se u središtu ovoga rada nalazi upravo govoreći subjekt, i to ponajviše kao orijentacijska točka prema kojoj se određuje sadržaj lingvističkih teorija. Drugim riječima, lingvističke teorije mogu se razlikovati prema statusu i položaju govorećeg subjekta u njima. Saussure je utoliko opće mjesto, ukoliko razrađeno uvodi problem strukture i strukturne određenosti u razmatranja o jeziku. Zato nas posebno zanima odnos između jezične strukture i govorećeg subjekta te sve implikacije međusobnih odnosa strukture i subjekta. Ta se dihotomija proteže i uzduž drugih sosirovskih dihotomija. Tako, primjerice, dihotomija između jezika (langue) i govora (parole) odgovara dihotomiji između kolektivnog i individualnog, odnosno između strukture i subjekta, što zapravo predstavlja samo suštinsko uopćenje svih sosirovskih dihotomija.

Osim toga, cilj ovoga rada jest uspostaviti teorijski okvir za mogućnost metalingvistike kako bi se uopće mogla razriješiti dihotomija između jezične strukture i govorećeg subjekta te kako bi se mogao dati odgovor na pitanje o konstituciji govorećeg subjekta. Prema tome, pretpostavka aktivnog postojanja metajezične svijesti ili sposobnosti, odnosno, posljedično, jezičnog upravljanja, ključna je za izlaženje iz začaranoga kruga stvorenog ostajući u rigidno postavljenoj dihotomiji koja je implicitno ili eksplicitno prisutna u mnogim lingvističkim teorijama, neovisno o tome jesu li prethodile ili ne zasnivanju moderne opće lingvistike u sosirovskom ruhu. Da bi se metalingvistika mogla uspostaviti te da bi se objasnila metajezična sposobnost, pomoći mogu filozofska, politička i pragmatička razmatranja koja uključuju odnos između jezika i mišljenja, odnose moći i hegemonije koji oblikuju jezik te karakter jezičnih iskaza u svojoj kontekstualnoj uvjetovanosti.

Neovisno o sosirovskim postavkama i metalingvističkom pokušaju nadilaženja, postavlja se temeljno pitanje je li govoreći subjekt proizvod jezične strukture ili su jezične strukture njegov proizvod? Drugim riječima, traži se logičko-ontološko prvenstvo strukture ili subjekta. Stoga se lingvističke teorije mogu razlikovati prema tome smatraju li govoreći subjekt funkcijom jezičnog sistema (sustava pravila, strukture, kulturnih kodova, simboličkih obrazaca i sl) ili ne. Točnije, jesu li jezici nomenklature ili nisu - Saussure izričito tvrdi da nisu. ${ }^{3}$ U slučaju primata jezične strukture

pretpostavki ta da sve teorije koje, prešutno ili ne, sadržavaju ovakve dihotomije sadržavaju ujedno i „ostatak” koji valja razriješiti.

3 Saussure kaže: „Za neke je ljude jezik, doveden na svoje temeljno načelo, neka vrsta nomenklature, to jest popis riječi koje odgovaraju isto tolikom broju stvari. Takvo je shvaćanje 
operira se metaforom „oruđa”, što implicira da postoji posredna kategorija između jezika i svijeta (tj. jezičnog i izvanjezičnog svijeta), a u slučaju primata govorećeg subjekta metaforom „leće”, što implicira odnos preslikavanja. To je ključna, makar grubo postavljena, distinkcija.

Prije prelaska na pokušaj razrješenja dihotomije između ovih dvaju pristupa, valja naglasiti da nije cilj relativizacijom obaju pristupa umanjiti njihovu spoznajnu vrijednost, već samo ukazati na neodrživost referiranja unutar tog okvira. Usto je potrebno uvesti pojam koji čini kariku koja nedostaje ako želimo izbjeći relativizam. Riječ je o metalingvistici kojom se nastoji s više razine reflektirati o prirodi odnosa između jezične strukture i govorećeg subjekta, stavljajući ih u kontekst aktivne svijesti o upotrebi jezika, dijaloških odnosa ovisnih o socijalnim i kulturnim kodovima te uloge odnosa moći. Zato će jezično upravljanje, kao ključni koncept, biti provučen kroz filozofsku, političku i pragmatičku dimenziju. Konstitucija govorećeg subjekta tako je omogućena metajezičnom sposobnošću koja sâm jezik osvještava kao predmet upotrebe.

\section{Jezično upravljanje, govoreći subjekt i metajezična sposobnost}

Svaka se lingvistička teorija može promatrati s obzirom na to kako postavlja odnos između strukture i subjekta - to nije isključivo odlika sosirovskoga rigidnog strukturalizma. Ostajući na tlu te dihotomije, ostaje se i dalje na koncepciji jezika in se i per se. Drugim riječima, odgovor na pitanje o konstituciji govorećeg subjekta daje se kao odgovor ili na pitanje „kako je subjekt upravljan?” ili „kome pripada jezik?” Ako se usmjerimo na to da je subjekt upravljan impersonalnom, apstraktnom strukturom, onda smo afirmirali primat strukture. Ako se usredotočimo na to da je subjekt već taj kojemu pripada jezik, onda smo afirmirali njegov primat, a strukturi dodijelili sekundarnu ulogu. U prvom slučaju uvijek ostaje pitanje autonomije govorećeg subjekta te tako i mogućnosti njegova slobodnog djelovanja kroz jezičnu praksu. U drugom slučaju nerijetko se problem reducira na pitanje akribije i poštovanja logičko-gramatičkih limita, a jezična praksa

prijeporno zbog mnogo razloga. Ono pretpostavlja već gotove ideje koje postoje prije riječi..." (Saussure 2000: 121). Dakle, Saussureova kritika jezika kao nomenklature svodi se na kritiku odnosa paralelizma između stvari u izvanjezičnom svijetu i riječi kojima su tobože te stvari reprezentirane. Kada bismo pretpostavili da su jezici nomenklature, nužno bismo dali primat govorećem subjektu nad jezičnom strukturom jer je onda on tu postavljen kao autonomni akter koji samo imenuje ono što susreće kao objektivno dano u vanjskom svijetu. 
kao društvena praksa ostaje ostavljena po strani - proizvodnja značenja i centralna uloga značenja u komunikaciji kao društvenom aktu kod ovakvog pristupa ostaje u većoj mjeri zanemarena. ${ }^{4}$ Stoga, umjesto navedenih pitanja koja se prešutno postavljaju i omogućuju smjer lingvističkih teorija, pravo je zapravo pitanje „tko upravlja jezikom?”. To pitanje stavlja problem na metajezičnu, štoviše, na metaznanstvenu razinu. Tek će pokušaj odgovora na to pitanje omogućiti prevladavanje dihotomije između subjekta i strukture. To znači da je potrebno navesti pretpostavke o jeziku koje otvaraju mogućnost metajezične sposobnosti i metalingvistike.

\section{1. „Tko upravlja jezikom?” - što to znači?}

Ovo pitanje koje se tiče jezičnoga upravljanja zapravo je pitanje o metajezičnoj sposobnosti te o mjestu govorećeg subjekta koje je u većini dosadašnjih lingvističkih teorija eksplicitno odsutno. Kako god definiramo jezik, bilo kao „sustav znakova”, „emanaciju duha”, „urođeno univerzalno znanje”, „utjelovljenje uma” ili drugačije, u svakom ga se od navedenih slučajeva razmatra neovisno od činjenice da njime upravljaju govornici i slušatelji, tj. subjekti jezične prakse. ${ }^{5}$ Drugim riječima, pri svemu dosad navedenom operira se pretpostavkom o nesvjesnoj prirodi jezika.

Nasuprot tome, ovdje ćemo postulirati pretpostavku o svjesnoj prirodi jezika, zahvaljujući refleksivnom, metajezičnom aspektu na kojemu će biti težište ove rasprave. Jezično upravljanje predstavlja sposobnost razvijenu metajezičnom sviješću, koja je zapravo samo „druga strana same jezične sposobnosti”. ${ }^{6}$ Prema tome, objašnjenje i reafirmacija metajezičnosti bit će

4 To se odnosi i na odlike Bloomfieldova biheviorizma i Chomskyjeva mentalizma. U oba slučaja može se vidjeti da te teorije žrtvuju semantičku i konceptualnu analizu u korist nekog oblika psihološko-logičkog redukcionizma (kod Bloomfielda je riječ o biheviorističkom anti-psihologizmu, kod Chomskog o krajnje individualiziranom nativističkom mentalizmu).

5 Ovime se još ne govori kako i pod kojim pravilima govornici i slušatelji upravljaju jezikom - autonomno ili pod određenim strukturnim pravilima, no to i nije više pitanje radi se o tome da se uopće postulira sposobnost jezičnog upravljanja koje je samo po sebi moguće zahvaljujući metajezičnoj sposobnosti, što ćemo vidjeti u nastavku.

6 Ovdje je svjesno naznačena aluzija na Saussureovu analogiju s istim listom papira: „Jezik se može usporediti i s listom papira: misao je lice, a glas je naličje; ne možemo rezati lice, a da istodobno ne režemo naličje; jednako tako u jeziku ne možemo odvojiti glas od misli ni misao od glasa" (Saussure 2000: 179). U ovome se kontekstu želi reći da je na isti način nemoguće razdvojiti jezično upravljanje (čime odgovaramo na pitanje „tko upravlja jezikom?") od metajezične sposobnosti. Drugim riječima, to znači da su si jezično upravljanje 
prva pretpostavka na kojoj se razvija teorija jezičnoga upravljanja. Metajezičnu sposobnost možemo smatrati sastavnicom refleksivne i dijaloške prirode jezika i komunikacije, a kako je dugo vremena metajezičnost promatrana odvojeno od jezika samoga te subjekata jezične prakse, dijaloška priroda jezika promatrana je samo kao funkcija informacijske razmjene, a ne kao stvar intrinzične prirode jezika. Drugim riječima, subjektivnost govornika/slušatelja dugo se vremena nalazila izvan lingvističkih istraživanja. ${ }^{7}$ Tek su neki nelingvisti zainteresirani za jezik i njegovu ulogu, poput Mihaila Bahtina, stavili primarno težište na dijaloški karakter jezika. ${ }^{8}$ Druga je pretpostavka rekonstrukcija govorećeg subjekta na čemu se može razvijati teorija jezičnoga upravljanja. Jezično je upravljanje tako vještina upravljanja vezom između jezične i metajezične sposobnosti, a baveći se jezičnim upravljanjem kao predmetom, bavimo se zapravo metajezičnim istraživanjem, tj. metalingvistikom, o čemu više kasnije u zaključku. S obzirom na ove pretpostavke, možemo razviti nekoliko pripadajućih hipoteza koje onda valja provesti kroz više dimenzija u kojima se manifestiraju različiti aspekti jezične prirode i jezične funkcije. Te će nam hipoteze pomoći da razvijemo teorijski okvir za metalingvistiku. Prva hipoteza glasi: jezik nije nesvjesna, instinktivna sposobnost, nego svjesna aktivnost uma koja sadrži obilježja funkcionalne komunikacijske interakcije i socijalnih ideologija. Druga: jezik nije puka sposobnost reprezentacije i simbolizacije, već također i metajezična (refleksivna, dijaloška) sposobnost i treća: metajezična sposobnost omogućava govorećem subjektu (govorni-

i metajezična sposobnost međusobno pertinentni te da, što će uskoro biti objašnjeno, metajezik nije ništa drugo nego sâm jezik.

7 Sosirovskim dihotomijama upravo je to vrlo rigidno postavljeno - „lingvistika govora” tek je sporedni i podređeni dio lingvistike kao znanosti o jezičnoj strukturi, a govor (parole) tek je drugi par, znanstveno manje relevantan, dihotomije „jezik-govor” te je njegova priroda bitno individualna i kontingentna. Zbog takvih pretpostavki, koje konceptualno strogo razdvajaju karakteristike jezika i govora, Saussure je imao velikih problema s objašnjenjem prijelaza i njihovih međusobnih uvjetovanosti. Eugenio Coseriu (2011) uvodi trihotomiju: „sustav-norma-govor”, pri čemu bi upravo norma trebala predstavljati dodirnu točku između jezika (sustava) i govora (realizacije). Coseriu je u nastavku definira kao ono što je u konkretnom govorenju ponavljanje prethodnih modela, a nameće se pojedincu u vidu društvenih i kulturnih prisila (ibid. 75-76).

8 Mihail Bahtin u svojem djelu Marksizam i filozofija jezika (1980) afirmira dijalošku interakciju između „ja” i „ti” kao istinsku dijalektiku jezika nasuprot sosirovskom „apstraktnom objektivizmu” i (neo)romantičarskom ,individualističkom subjektivizmu”. Bahtinova kritika lingvistike jest kritika „monologizma” i njezine nemogućnosti dolaženja do metalingvističke razine za koju je dijaloški karakter nužna pretpostavka. 
ku/slušatelju) da konstituira svoju subjektivnost. Dimenzije kroz koje valja provesti ove hipoteze jesu filozofska, politička te pragmatička. Filozofska dimenzija odnosi se na najapstraktniju razinu, na kojoj se proučava odnos između jezika i svijesti, jezika i mišljenja te jezičnoga i izvanjezičnoga svijeta. Politička dimenzija uvodi konkretnije koncepte moći i hegemonije te socijalizacije i simboličke moći, što se proučavalo na rubovima lingvistike te čemu je znatno pridonijela sociologija i kritička teorija. Konačno, pragmatička dimenzija najviše je zaokupljena raspadom dihotomije između deskriptivnosti i performativnosti te odnosom između metajezika i pragmatičkih komunikacijskih uvjeta.

Metalingvistikom se, dakle, može smatrati metajezično istraživanje koje se bavi samim jezičnim upravljanjem, a kao što smo maločas vidjeli, pretpostavka jezičnog upravljanja jest svijest o jeziku kao predmetu u svim njegovim dimenzijama - za simboličko-reprezentativne, komunikacijske, performativno-pragmatičke te druge funkcije. Prema tome, metalingvistika zaokružuje složeni odnos između jezičnog upravljanja, metajezične svijesti, tj. sposobnosti te metajezika u gore navedenim trima dimenzijama. Od gore navedenih triju hipoteza prva koja govori o jeziku kao svjesnoj aktivnosti jest ključna jer iz nje proizlaze i ostale hipoteze koje se odnose na metajezičnu sposobnost i konstituciju govorećega subjekta. Wallace Chafe (2009) dobro primjećuje da je odnos između svijesti i jezika u velikoj mjeri zanemarivan u lingvističkim teorijama i istraživanjima, za što optužuje i frojdijansku paradigmu koja afirmira nesvjesno, kao i i anti-psihologističke tendencije:

„Osim mogućnosti da ustvari nema odnosa vrijednog razmatranja, razlozi za ovo zanemarivanje uključuju dominaciju unutar biheviorističke psihologije, koja odbacuje svijest kao da nema znanstvenu vrijednost; paralelni utjecaj frojdijanske psihologije, koja je svoj veći interes pronašla u podsvjesnom nego u svjesnom; te unutar lingvistike sklonost protiv 'psihologiziranja"' (Chafe 2009: 135)

Prilikom tog opažanja Chafe ipak ne zanemaruje ulogu nesvjesnih struktura i procesa o kojima ovisi upotreba jezika:

„Premda i sadržaj i tok svijesti mogu biti djelomično nesvjesno determinirani, te premda upotreba jezika može znatno ovisiti o nesvjesnim mentalnim strukturama i procesima, u isto će 
vrijeme svijest biti tu pretpostavljena kao mjesto gdje pamćenje, zamišljanje, procjenjivanje i govorenje dolaze zajedno da proizvedu i misao i jezik" (ibid. 136).

Ovo samo dokazuje kako ne postoji samo po sebi problem s koncepcijom koja pretpostavlja dihotomiju između jezične strukture i govorećeg subjekta, već da je ostajanje samo unutar okvira te koncepcije nedostatno, odnosno da ne daje odgovore na sva pitanja koja se javljaju u pogledu istraživanja jezične djelatnosti, uloge i naravi jezika. Konačno, može se reći da se metalingvistika bavi konstitucijom govorećeg subjekta izvan okvira koji ostaje isključivo na razini odnosa između govorećega subjekta i jezične strukture.

\subsection{Jezik, metajezik i metajezična svijest}

Kako to metajezična svijest može omogućiti izlazak izvan začaranoga kruga strukture i subjekta? Ako je, dakle, jezik svjesna djelatnost, onda mora postojati i jezik o jeziku, tj. onaj jezik koji može reflektirati sâm jezik - metajezik. Time nam se otvara mogućnost metajezičnog upravljanja, što je i glavni cilj u ovoj raspravi kako bismo potvrdili gore navedene hipoteze. Ako je za jezično upravljanje potrebna metajezična sposobnost, onda postoji i nešto što se naziva metajezično upravljanje i ono se više ne odnosi na svjesni pokušaj ostvarenja komunikacijskog cilja u izvanjezičnoj stvarnosti, kao što je to slučaj kod jezičnog upravljanja, nego se odnosi na sâm jezik kao kôd. Metajezična sposobnost tako nije ništa drugo nego sposobnost produkcije metajezika. ${ }^{9}$ Zato nam je od izuzetne važnosti Jakobsonova metajezična funkcija. Tu vidimo da je metajezik sâm prirodni jezik, ali koji ima performativnu funkciju za formiranje diskursa jer determinira njegovu vrstu, što znači da eksternalizira znanje koda na socijalno prepoznatljiv način. Tako Jakobson kaže:

„Daleko od toga da budu ograničene na sferu znanosti, metajezične operacije dokazuju da su integralni dio verbalnih aktivnosti. Kada god pošiljatelj i/ili primatelj treba(ju) provjeriti služe li se istim kodom, govor je fokuiran na sâm kôd te tako izvršava metajezičnu funkciju" (Jakobson 1985: 116-117).

9 Moglo bi se reći da je metajezična sposobnost još jedna bitna differentia specifica ljudskog jezika u odnosu na druge semiološke sustave koji se nerijetko neprecizno nazivaju jezicima (ponajviše se misli na različite semiološke sustave kojima se mogu služiti neke životinjske vrste). 
Slično tvrde i Elizabeth Mertz te Jonathan Yovel:

„Govornici imaju različite stupnje svijesti metajezika kako se odnose te kako performativno oblikuju komunikaciju. Ponekad sudionici eksplicitno prepoznaju metajezičnu razinu koja strukturira konverzaciju, no ponekad strukturirajuća uloga metajezika može biti djelomično ili potpuno prikrivena, operirajući na suptilne načine kojih su govornici djelomično ili potpuno nesvjesni. Čak i u tim slučajevima, govornikova djelomična svijest ili čak potpuno nerazumijevanje metajezika može pomoći pri oblikovanju jezične interakcije" (Mertz i Yovel 2009: 250).

Mertz i Yovel baveći se metajezikom nadilaze Jakobsona u prigovoru da se nije osvrtao na metajezičnu svijest. To bi podrazumijevalo da govoreći subjekt mora posjedovati sposobnost da se sâm distancira od svog ,jezikaobjekta" te da njega samoga postane svjestan kao predmeta. Kod Jakobsona metajezična je funkcija samo jedna od jezičnih funkcija u komunikacijskom modelu te joj nije dodijeljena funkcija višeg reda u odnosu na druge jezične funkcije. Jedna od poanti ove rasprave trebala bi se sastojati u tome da se metajezična funkcija stavi na višu razinu, kontrolnu i bitno determinirajuću, u odnosu na ostaje jezične funkcije. To znači da se time prelazi ranije prešutno prihvaćena teza o nesvjesnosti jezika i njegove upotrebe, o čemu smo se osvjedočili prilikom pregleda lingvističkih teorija, te da se konačno dolazi na teren na kojemu se jezik promatra s metalingvističke razine kao svjesna djelatnost. Daljnje ilustracije radi, kod filozofa Jürgena Habermasa nailazimo na tzv. „metajezični konsenzus”, što znači pretpostavku operiranja istim kodom (da bi komunikacija uopće bila moguća). Po njemu taj se konsenzus ostvaruje, prešutno ili ne, sporazumom govornih aktera prije uspostavljanja komunikacije. ${ }^{10} \mathrm{I}$ u tom se slučaju može jasno vidjeti kako metajezična razina predstavlja onu razinu koja je uvjet mogućnosti za ostvarenje ostalih razina, tj. da je metajezična funkcija uvjet mogućnosti za ostvarenje drugih jezičnih funkcija. Upravo nam tu pomaže metalingvistika.

\subsection{Metalingvistički model}

Metalingvistički model, baziran na gornjim hipotezama, možemo shematski predočiti i ukratko objasniti na sljedeći način. Vidljivo je da možemo razlikovati viši i niži red, odnosno drugi i prvi red. Jezična razina,

10 O tome v. više u Habermas (1984). 
koju čine jezična struktura, govoreći subjekt te njihov dijalektičko-dijaloški odnos, pripada razini nižeg (prvog) reda; metajezična razina, koju čine metajezična sposobnost i metajezik, pripada razini višeg (drugog) reda. $\mathrm{Na}$ obje razine nalazi se jezično upravljanje, pri čemu se može razlikovati jezično upravljanje nižeg reda i jezično upravljanje višeg reda. Prvo se odnosi na svjesnu poziciju govorećeg subjekta koji ulazi u interakciju s jezičnom strukturom te koji pravila iz nje primjenjuje i prilagođava $u$ određenoj komunikacijskoj situaciji; potonje se odnosi na refleksivni odnos koji se ima prema samom jeziku (govoreći subjekt operirajući metajezikom reflektira o samom jeziku, tj. odnosi se prema njemu kao predmetu). Metajezik je moguć zahvaljujući metajezičnoj sposobnosti (svijesti) koja je krajnje nadređeni segment. Metajezično upravljanje tako uključuje svjesnost, intencionalnost i refleksivnost kao nužne uvjete za upravljanje jezikom uopće. Iz toga je vidljivo kako se Jakobsonova metajezična funkcija potpuno ostvaruje na višoj razini, dok ostale funkcije o kojima govori Jakobson pripadaju nižoj razini, iz čega se može zaključiti da je upravo metajezična funkcija nadređena funkcija u odnosu na druge jezične funkcije, što iz Jakobsonova modela još nije bilo razvidno. Tu smo opasku uz Jakobsonove jezične funkcije već mogli vidjeti. Nadalje, metajezik je konstituiran kao i sâm jezik - odnos između strukture i subjekta jednak je kao i kod jezika, no za ovu svrhu nije bilo potrebno na višoj razini raditi tu raščlambu jer se ona zapravo događa na nižoj razini. Drugim riječima, kada metajezik uopće razmatramo s tog aspekta, automatski zalazimo na nižu razinu - metajezik se po svojoj formi ne razlikuje od jezika. U nastavku ćemo vidjeti kako se jezično upravljanje odvija te kako metajezična sposobnost djeluje u izdvojenim dimenzijama - filozofskoj, političkoj i pragmatičkoj, te kako se unutar njih mogu potvrditi tri glavne hipoteze uvedene u ovom poglavlju.

\section{Filozofske, političke i pragmatičke pretpostavke konstitucije govorećeg subjekta}

\subsection{Filozofske pretpostavke konstitucije govorećeg subjekta}

Govoreći o filozofskim pretpostavkama orijentiramo se prvenstveno na odnos između jezika i mišljenja koji zaokuplja pažnju lingvista i filozofa jezika unazad više stoljeća i tisućljeća. Zbog opširnosti problematike ovdje će pažnja biti usredotočena na odnos između jezika i mišljenja koji će biti razjašnjen preko Benvenisteove rasprave o prirodi sosirovskoga jezičnog znaka. 
O shvaćanju odnosa između jezika i mišljenja već smo se upoznali prilikom pregleda lingvističkih teorija. Prema tome, ugrubo promatrano možemo razlikovati dva suprotstavljena gledišta na odnos između jezika i mišljenja - ono prema kojemu jezik prethodi misli te ono prema kojemu misao prethodi jeziku. Slijedeći prvo stajalište izvodi se lingvistički relativizam, a u krajnjoj konzekvenci i lingvistički determinizam, dok slijedeći drugo stajalište konzekventno se razvija lingvistički univerzalizam. Kao glavne primjere stajališta da jezik prethodi misli imamo još u srednjem vijeku modističku školu, a svoje artikuliranije nastavke dobiva u humboldtovskom romantizmu te ponajviše u Sapir-Whorfovoj hipotezi. S druge strane, primjeri za stajalište da misao prethodi jeziku obično su završavali u formalističkim i logicističkim teorijama koje svoje podrijetlo vuku ponajviše od racionalističke i empirističke teze o autonomnosti subjekta (što je u ovom slučaju zapravo autonomija misli) - od gramatike Port-Royal sve do Noama Chomskog čiji su preteče bili snažno pod utjecajem logičkog pozitivizma. Vezano uz sve navedeno, nama se postavlja pitanje što zapravo znači pitanje primata jezika ili mišljenja - misli li se na stvarni historijski primat, ili na primat u logičkom ili ontološkom smislu? I koliko nam je uopće korisna afirmacija ijedne od navedenih teza s obzirom na to da svaka zapravo dovodi u circulus vitiosus.

Kako bismo ovaj problem bolje razjasnili i nastojali ga nadići, opet moramo zaviriti u Saussureov Tečaj gdje se zapravo krije mogućnost odgovora na ovo pitanje i odakle možemo izvući temelje za metalingvističku hipotezu. Mjesta na kojima Saussure govori o prirodi jezičnog znaka smatraju se jednim od najkontroverznijih i najdiskutabilnijih mjesta u Saussureovu opusu. Jezični je znak za Saussurea psihološki entitet s dvjema međusobno nerazdvojivim stranama - označiteljem (akustičkom slikom, planom izraza) i označenim (pojmom, planom sadržaja) te mu je jedna od bitnih karakteristika arbitrarnost:

„Veza koja spaja označitelja s označenikom proizvoljna je, to jest arbitrarna, ili, budući da pod terminom znak razumijevamo cjelinu koja proistječe iz udruživanja jednog označenika i jednog označitelja, možemo reći i jednostavnije: jezični je znak arbitraran" (Saussure 2000: 124) ${ }^{11}$

11 Ovaj je dio popraćen izuzetno važnim komentarom Tulia de Maura (2000: 488) u kojemu on naglašava kako su izdavači izbacili možda ključnu riječ u ovom citatu - 
Ovdje se pronalaze dvije međusobno neekvivalentne teze - jedna je ta da je veza spajanja označitelja i označenog arbitrarna, a druga da je jezični znak arbitraran. Čini se da je Saussure nastojao izjednačiti te dvije tvrdnje, no iščitavajući razne komentare i osvrte na ova mjesta u Tečaju, naročito Benvenisteov, mišljenja smo kako se upravo tu nalazi jedna bitna i ključna razlika. U svojem eseju Priroda lingvističkog znaka Emile Benveniste naglašava da označitelj i označeno jedan drugo prizivaju te da je njihova veza nužna (obligatorna): „Veza između oznake [označitelja, op.a.] i označenog nije proizvoljna; naprotiv, ona je nužna" (Benveniste 1975: 57). Ta misao zapravo potvrđuje Saussureov primjer s licem i naličjem istog lista papira, a Benveniste dodatno naglašava da bez pomoći jezičnih znakova ne bismo mogli razlikovati različite ideje i stvari te se pri tome poziva na samoga Saussurea (misao kao amorfna masa prije pojave jezika, odnosno prije pojave misli u jezičnom obliku). Na kraju Benveniste priznaje tezu o arbitrarnosti, ali samo iz tog razloga što tvrdi da je ona formulirana uslijed prešutnog pozivanja na samu stvar - na referent u prirodi (u tom je smislu onda ta veza nemotivirana). Ovo otvara brojna pitanja - na što se onda misli kada Saussure govori o arbitrarnoj vezi spajanja označitelja i označenog? S obzirom na to da iznošenje teze o arbitrarnosti jezičnoga znaka, odnosno arbitrarnoj vezi između dviju sastavnica jezičnoga znaka prethodi složenoj raspravi o nepromjenjivosti i promjenjivosti jezičnoga znaka, čini se da se ta teza odnosi na pretpostavljeni početak u logičkom smislu - ne u historijskom smislu jer do takvog početka, više puta napominje Saussure, niti ne možemo doprijeti. Taj pretpostavljeni početak u logičkom smislu zapravo je ontološki konstitutivan za jezični znak te je njegovo objašnjenje nužno kako bi se uopće moglo govoriti o prirodi jezičnoga znaka. K tome, ovdje vidimo koliko je zapravo od ključne važnosti, bar za izbjegavanje nejasnoća i poteškoća, nemarno izostavljeni prilog radicalement. Raspravljajući tako o karakteristikama nepromjenjivosti i promjenjivosti jezičnoga znaka Saussure nudi zaključak da obje međusobno kontrarne karakteristike proizlaze upravo iz arbitranosti jezičnoga znaka - jezik se oduvijek poznaje kao proizvod naslijeđa od proših naraštaja (pitanje stvarnog, historijskog početka tako uopće nije pitanje), što znači da je čimbenik konzervacije, dok se ujedno i mijenja pod pritiskom vremena, ali ga pojedinačni govornici

radicalement („radikalno”, „korjenito”, „temeljno”, prev.a.). Možda je, kako kaže Mauro, bila stvar sam u pleonastičkom sredstvu pojačavanja, no bliži smo uvjerenju kako je ovaj izraz zapravo ključan u objašnjenju arbitrarnosti jezičnoga znaka. 
volitivno ne mogu mijenjati. Drugim riječima, jezična djelatnost (langage) u cjelini (jezični znak sâm za sebe samo je poslužio kao teorijski konstrukt, njegova je funkcija uvijek u sustavu) počiva na stalnoj napetosti između sistemske stabilnosti i promjena, tj. jezičnih inovacija. To ustvari znači da je na djelu stalni odnos napetosti između govorećeg subjekta i jezične strukture u jedinici vremena, odnosno da se može govoriti o dijalektičkom odnosu između jezika i govora, između strukture i subjekta te u konačnici između jezika i mišljenja. Uzimajući u obzir element vremena možemo napustiti brojne nedoumice koje se stvaraju uslijed rigidnog sinkronijskog, odnosno statičnog promatranja jezika.

\subsection{Politička dimenzija jezičnog upravljanja}

Politička dimenzija već je unaprijed određena time da nikako ne govori o jeziku „u praznom hodu”, već o jeziku kao konkretnoj socijalnoj praksi jer inače temeljni pojmovi vezani uz nju (moć, hegemonija, ideologija, historičnost) ne bi uopće funkcionirali, niti bili potrebni. Prema tome, baveći se političkom dimenzijom jezičnog upravljanja i konstitucije govorećeg subjekta naglasak je stavljen na vezu raslojenosti društvene i jezične strukture, odnose moći među jezičnim akterima te na funkciju jezika kao poprišta borbe.

Pierre Bourdieu, francuski sociolog, u svojem djelu Što znači govoriti? (1992) nudi jednu kritiku dotadašnje lingvistike koja polazi upravo od gornjih pretpostavki. Prema njemu, glavnu karakteristiku Saussureove lingvistike predstavlja promatranje jezika kao predmeta razumijevanja, a ne kao sredstva akcije i moći. Nasuprot tome, Bourdieu smatra da se u jeziku ipak realiziraju odnosi snaga između govornika te da možemo govoriti o „ekonomiji jezičnih razmjena”, što je i podnaslov tog djela. Tako kaže:

„Svaki čin govorenja i, općenitije, svaka akcija zapravo je konjunktura, susret neovisnih kauzalnih nizova: tu su, s jedne strane, društveno oblikovane dispozicije jezičnog habitusa, koje impliciraju izvjesnu sklonost govorenju i izricanju točno određenih stvari (ekspresivni interes) i izvjesna sposobnost govorenja, definirana $u$ isto vrijeme i kao jezična sposobnost neograničenog stvaranja gramatički ispravnih diskursa i kao društvena sposobnost koja omogućuje da se tom kompetencijom primjereno služimo u određenoj situaciji; s druge strane, tu su strukture jezičnog tržišta, koje se nameću kao sustav specifičnih sankcija i cenzura" (Bourdieu 1992: 14). 
Ovdje vidimo kako Bourdieu shvaća jezičnu djelatnost te kako njegovi uvidi otkrivaju nedorečenosti u lingvistici koja se zatvorila u vlastito polje, odnosno promatra jezik in se i per se, izvan vlastitih društvenih uvjeta proizvodnje. ${ }^{12}$ To se odnosi i na Saussurea i na Chomskog i na Bloomfielda (njih Bourdieu eksplicitno spominje, ali nesumnjivo se radi o kritici lingvistike uopće). Takvo formiranje lingvistike kao znanstvene discipline omogućilo je i anticipaciju izvjesnog idealnog govorećeg subjekta, tzv. homo linguisticusa koji bi odgovarao homo economicusu u klasičnoj političkoj ekonomiji. Riječ je o praktički idealiziranom akteru koji je lišen svojeg položaja u društvenoj strukturi te za kojega se pretpostavlja da djeluje u „savršenom jezičnom tržištu” s ciljem maksimizacije komunikacijske koristi. ${ }^{13}$ Nasuprot tome, govorenje nije internalizirano korištenje pravila i kodova iz već dane apstraktne i monolitne jezične strukture, već usvajanje i korištenje određenih izražajnih stilova koji su prisutni u strukturnoj hijerarhiji. Bourdieu tako otkriva da govoriti monolitno i apstraktno o jeziku, kao što čini Saussure, zapravo znači prihvatiti službenu definiciju službenog jezika neke političke zajednice koji se širi govornom zajednicom kao legitiman te definira govornoga aktera, služi kao jezik javne komunikacije, omogućuje integriranost u jezičnu zajednicu i uvjet je uspostavljanja jezične dominacije. Bahtin (1980) je u tome vidio jedan oblik „postvarenja govora”, tj. fetišizacije jednog oblika govora, jednoga koda, a metalingvistiku je opisao kao memorandum protiv toga, kao pokušaj svjesnog nadilaženja otuđenja u jeziku/govoru. S obzirom na to, može se reći da metalingvistika vrši i emancipatornu funkciju, da figurira kao sredstvo osvještavanja. Metalingvistički čin tako bi bilo percipiranje jezičnoga znaka u odgovarajućim ideološkim sistemima. Do ovih uvida u Bahtina i Bourdieua, koji

12 Primjetno je dosta izraza koji su specifično „burdjeovski”, poput „dispozicije”, „polja”, „habitusa” i sl. Format i svrha ovog rada ipak je nešto skučenija da bi se moglo dublje ulaziti u glavne Bourdieuove pojmove, pa ćemo se ograničiti na shvaćanje jezika kao nositelja simboličke moći u raslojenoj društvenoj strukturi koja je u lingvista zanemarivana ili promatrana uniformno.

13 Tu se opet primjećuje sličnost s klasičnom političkom ekonomijom koja je na analogan način opisivala homo economicusa, racionalnog ekonomskog aktera koji djeluje s ciljem maksimizacije vlastitih potreba i preferenci na tržištu. Bourdieu (1992: 38) smatra da je „savršeni” jezični akter jednako daleko od realnog jezičnog tržišta kao i „savršeni” ekonomski akter od realnog ekonomskog tržišta s njegovim monopolima i oligopolima. Monopoli i oligopoli na „jezičnom tržištu” bili bi one jezične jedinice koje su nositelji veće (povlaštene) simboličke moći te čija je upotreba povezana s određenim položajem u društvenoj strukturi i koju različito primjenjuju različiti jezični akteri. 
sami nisu bili lingvisti, lingvistika kao disciplina u potpunosti je ili uglavnom apstrahirala od političko-ideoloških uvjeta reprodukcije jezika te povezanosti istih sa socijalnim i klasnim statusom govorećih subjekata. ${ }^{14} \mathrm{Iz}$ tog razloga zanemarivanja moći i hegemonije u samom jeziku nije bilo moguće ni razviti jednu teoriju jezičnog upravljanja i usredotočiti se na pitanje „tko upravlja jezikom?”. Feruccio Rossi-Landi (1981) na tom tragu smatra kako je Saussureov jezik javan, ali još nije društven te da kod njega nema ni riječi o samom postanku danoga jezika - drugim riječima, nema riječi o upravljanju njime. Svoje pak teze, slične nekima iz Bourdieuovih uvida u „ekonomiju jezičnih razmjena”, Rossi-Landi objašnjava u terminima robe, novca, rada, tržišta i kapitala. Tako jezične jedinice na neki način funkcioniraju kao robe na tržištu na kojemu se susreću akteri koji dolaze s različitom količinom kapitala i unaprijed dane moći. To objašnjava i kako jedna određena jezična jedinica biva prihvatljivijom te kako se vezuje uz legitimnost i viši položaj govornog aktera.

\subsection{Pragmatička razina - intencije i učinci jezičnih iskaza}

$\mathrm{Na}$ pragmatičkoj razini susrećemo se mnogo više s učincima koje jezični iskazi izazivaju bez obzira na kompleksnost izvanjezičnih okolnosti. Time se ne apstrahira od uronjenosti jezičnih iskaza u socijalni kontekst nego se samo veća pažnja pridaje jezičnim radnjama kao takvima, a proširenjem lingvistike na druge discipline (vidljivo u prethodnom potpoglavlju) pragmatika se upotpunjuje. Da se cijela lingvistika može dovesti u okrilje pragmatike, pokazuje nam nasljeđe kasnog Wittgensteina i tzv. filozofije običnoga jezika najviše oličene $u$ anglosaksonskim teoretičarima poput Johna Langshawa Austina. Kao preduvjet shvaćanja metapragmatičke razine kao bitne dimenzije jezičnog upravljanja nudi nam se raspad dihotomije između performativa i konstativa, što je i glavna teza Austinova djela Kako djelovati riječima. Također, mnogi suvremeni autori poput Jefa Verschuerena i Michaela Silversteina ovoj su tematici znatno doprinijeli baveći se metapragmatikom.

14 Kada se kaže da Bahtin i Bourdieu nisu bili lingvisti, misli se na lingvistiku u akademskom smislu, kao na određenu disciplinu u akademskom polju, dakle, koristi se u istom značenju kako i sâm Bourdieu vrši kritiku znanosti i akademskoga polja. No, gledajući i odnose unutar akademskog polja te između različitih disciplinarnih polja ovime je veoma vidljivo kako su i nelingvisti Bahtin i Bourdieu itekako utjecali na samo disciplinarno polje lingvistike (npr. na kritičku analizu diskursa). 
Austin (2014) nakon objašnjenja performativnih iskaza kojima daje prednost pred konstativnima (deskriptivnima) otkriva veliku rupu u strogom razgraničenju između ta dva tipa iskaza. Tako na primjeru „u polju je bik" pokazuje kako je strogo razgraničenje između konstativa i performativa nemoguće te da za preciziranje ispunjava li takav iskaz više konstativnu ili performativnu funkciju treba iskoristiti još mnogo više nego što nudi i sâm kontekst. Drugim riječima, Austin za teoriju govornih činova ne nudi više, kao što je nalagala ranija analitička filozofija, rečenicu kao temeljnu jedinicu, već uključuje čitav diskurs, što nije kontradiktorno s time da i jedna rečenica može sačinjavati diskurs. Međutim, u diskurs je uključena i čitava izvanjezična situacija koja bitno situira iskazivača govornoga čina, odnosno govorećeg subjekta. Granica između konstativa i performativa postaje sve fluidnijom te se nameće pitanje gramatičkog ili leksikografskog kriterija za razlučivanje. Austin to pobija nakon navođenja primjera tvrdeći naprosto banalnu činjenicu da se ista rečenica $u$ različitim (izvanjezičnim) prigodama može upotrebljavati na više načina. Jedan od Austinovih primjera koji se ovdje navodi („u polju je bik”) može biti sastavnicom više jezičnih igara, a da bismo raspoznali o kojoj se jezičnoj igri radi valja uključiti cijelu situaciju koju sačinjava jezični i izvanjezični kontekst. Na formalnoj logičko-gramatičkoj razini taj iskaz djeluje kao deskriptivni, no tek iz cijele jezične igre (jednog diskursa) razazanjemo radi li se o performativnom ili konstativnom iskazu, točnije, je li iskaz u većoj mjeri performativnog ili konstativnog karaktera. Performativni karakter ovog iskaza može se očitovati u sljedećim implikaturama: „ne idi u polje” ili „makni se s tog mjesta”, dok se presuponira da je bik opasna životinja. Austin je ovakvim stajalištima, na bazi kasnog Wittgensteina (1998), izazvao pravu revoluciju u filozofiji običnog jezika, pragmatici i lingvistici općenito, a pragmatičari nakon njega poput Johna Searlea i Geoffreya Leecha samo nastavljaju dalje razvijati teoriju govornih činova.

Raspad dihotomije između konstativnih i performativnih iskaza preduvjet je za shvaćanje metapragmatičke razine koja ovdje figurira kao bitna dimenzija metajezične sposobnosti. U tom bi se smislu metapragmatika trebala baviti refleksijom jezične situacije, konteksta, u kojemu određeni iskaz funkcionira na ovaj ili na onaj način, a svjesni pragmatički akter raspoznaje (metajezično, tj. metapragmatički) pogodan trenutak, odnosno situaciju, da iskoristi određeni tip jezičnoga iskaza. Taj se postupak ne bi smio svesti samo na cost-benefit analizu radi provjere uspješnosti 
komunikacijskoga čina, već bi se trebao uključiti i moment društvene agonistike, na tragu teza iznesenih $\mathrm{u}$ prethodnom potpoglavlju. Tako $\mathrm{u}$ pragmatičkoga aktera ne gledamo samo koliko se on svjesno trudi da ostvari što uspješniji komunikacijski čin (prenošenje što više relevantnih informacija u govornoj interakciji), nego i koliko on u tome uspijeva prezentirati moć nad drugim govornim akterom i izboriti se za izvjesna značenja. Zato pragmatika bez socijalno-političke dimenzije ne može dati pune odgovore ni na pitanja o performativnom karakteru jezičnih iskaza jer ta performativnost ostaje lebdjeti u zraku, funkcionirati „u praznom hodu".

\section{Mogućnost i uloga metalingvistike. Zaključna razmatranja}

Metalingvistika se susreće s problemom koji nadilazi njene mogućnosti. Već se na više mjesta moglo vidjeti da je riječ o metanarativu, tj. metajeziku univerzalnog karaktera koji bi bio mjerilo izvan pojedinih jezičnih igara prema kojemu se i kalibrira jezično upravljanje te koji bi bio jamac metajezične sposobnosti. To je potrebno da se izbjegne relativizam i inkomenzurabilnost. Čemu služi metajezik i metajezična sposobnost ako se ne može univerzalizirati i postaviti jedinstveno za sav pluralitet koji susrećemo u jezičnoj djelatnosti? U tom slučaju gubi svoju „metarazinu” i nema ga smisla postavljati na kvalitativno višu razinu u odnosu na jezik. Ako se prihvati relativizam, onda duboko dovodimo u pitanje temeljnu funkciju same jezične djelatnosti - komunikativnu funkciju, a već smo na više mjesta naznačili da su metajezične intervencije tu da omoguće bolje ostvarenje komunikativne i drugih funkcija te da upravljaju jezičnom djelatnošću uopće onako zbog čega i ona postoji kao specifično ljudska djelatnost.

Vodeći se ipak time da je jezik svjesna djelatnost omogućena metajezičnom sposobnošću što omogućava i konstituciju govorećega subjekta u danom okviru, riješile su se i dihotomije koje su bile, prešutno ili ne, nametnute u većini lingvističkih teorija. Metalingvistika je ujedno i partikularna (specifična) i univerzalna, što je općenito slučaj s metajezicima. To znači da ona, s jedne strane, reflektira partikularne jezične igre u kojima se oblikuju pojedini određeni govoreći subjekti, za pojedine jezične prakse i govorne zajednice, ali nam s druge strane pokazuje i da se istina konstituira u samom jeziku jer je iz njega samoga nemoguće izaći u potrazi za arhimedovskom točkom. Drugim riječima, ako bismo metarazinu tražili izvan samoga 
jezika, onda uopće ne bismo tražili metajezik ${ }^{15}$ ili, uopćeno govoreći, neki metanarativ, te bi cijela ova rasprava unutar lingvistike i filozofije jezika postala izlišna. Postavlja se pitanje zašto uopće tražiti neko izvanjsko mjerilo, neki izvanjski kriterij kada sama misao ne dopire izvan okvira jezika? ${ }^{16} \mathrm{U}$ tom je smislu pretpostavka nečega izvan predmeta-jezika, a što bi služilo kao mjerilo, puka skolastička pretpostavka i ne može nas odvesti mnogo dalje od paušalnog postavljanja izvanjskoga kriterija koji bi, znanstveno gledajući, predstavljao obično nagađanje. Zato metajezična sposobnost i jezično upravljanje pomažu u osvještavanju samog predmeta korištenja - jezika. Vodeći se gornjim spoznajama to znači da metajezik mora biti primjenjiv i na sâm metajezik, ali to također nalaže da tu mora biti i granica - u suprotnom bismo upali u beskonačni regres. Drugim riječima, u metodološke i heurističke svrhe mora se staviti granica nakon metarazine, a s tim nema problema ako se vodimo pretpostavkom da je jezik kriterij spoznaje s obzirom na to da za drugi kriterij ni ne znamo.

Konačno, refleksija jezika kao predmeta u brojnim lingvističkim teorijama ne bi bila moguća bez principa po kojemu se može „objektivirati subjekt objektivacije". Konkretno to znači da se govoreći subjekt mora učiniti objektom jer se jezik proučava i spoznaje samo preko govorećeg subjekta. Pitanje konstitucije govorećeg subjekta tako više ne ostaje pitanje primata strukture ili subjekta, već pitanje metalingvističke refleksije i na strukturu i na sâm subjekt, odnosno na njihove uvjete i granice. ${ }^{17}$ Jezik čini i jezikom se čini (i niža i viša razina jezične djelatnosti) jedini zaokruženi sistem znanja koji poznajemo, pa nema smisla tražiti izvanjsko mjerilo koje bi ionako uvijek bilo paušalnoga, neodređujućega karaktera. $\mathrm{K}$ tome, žrtvujući jezik kao univerzalni spoznajni kriterij, žrtvujemo i sâm svijet te

15 Već je spomenuto da metajezik nije ništa drugo nego sâm jezik - on vrši funkciju drugoga reda i ima regulativno-kontrolnu ulogu, no po svojoj formi i sadržaju ne razlikuje se od jezika prvoga reda (to je razvidno već kod Jakobsona, iako još ne u terminima višeg i nižeg reda).

16 Pri ovome se misli na bilo koji semiološki sustav koji je konstituiran prema pravilima jezika - u to je uključena pretpostavka da su misli već u sebi konstituirane kao znakovi. Točnije, prilikom svakog spominjanja jezika misli se na bilo koji semiološki sustav koji se dâ proučavati na način kao i jezik.

17 Ovime se odriče mogućnost proučavanja jezika in se i per se, što je već na više mjesta kritizirano jer se uvjeti i granice unutar kojih baratamo s određenom jezičnom strukturom i određenim govorećim subjektom nalaze izvan samoga jezika kao zatvorene, „savršene” cjeline, kakva je zamišljana, primjerice, u Saussurea i Chomskog. 
upadamo u spoznajni pesimizam koji ionako demantira praksa i historičnost. Stoga, ako je ovaj rad bio započet problematskom parafrazom koja je glavna misao Saussureova Tečaja, onda može biti završen okončavanjem postavljanja pitanja na koja ionako nećemo imati prilike odgovoriti, pa nisu ni vrijedna olakog prihvaćanja relativizma.

„Granice moga jezika znače granice moga svijeta” (Wittgenstein 1987: 147). ${ }^{18}$

\section{Literatura}

Austin, John Langshaw (2014) Kako djelovati riječima, Disput, Zagreb.

Bahtin, Mihail (1980) Marksizam i filozofija jezika, Nolit, Beograd.

Benveniste, Émile (1975) Problemi opšte lingvistike, Nolit, Beograd.

Bourdieu, Pierre (1992) Što znači govoriti? Ekonomija jezičnih razmjena, Naprijed, Zagreb.

Chafe, Wallace (2009) „Consciousness and language”, Cognition and Pragmatics, ur. Sandra, Dominiek et al, John Benjamins Publishing Company, Amsterdam, 135-145.

Coseriu, Eugenio (2011) Teorija jezika i opća lingvistika, Disput, Zagreb.

Habermas, Jürgen (1984) The Theory of Communicative Action, vol. I, Polity Press, Cambridge.

Jakobson, Roman (1985) „Metalanguage as a linguistic problem”, Selected Writings, vol. VII, ur. Rudy, Stephen, Mouton, New York, 113-121.

Mauro, Tulio de (2000) „Uvod i komentar”, Saussure, Ferdinand de. Tečaj opće lingvistike, Institut za hrvatski jezik i jezikoslovlje, Zagreb.

Mertz, Elizabeth i Jonathan Yovel (2009) „Metalinguistic awareness”, Cognition and Pragmatics, ur. Sandra, Dominiek et al, John Benjamins Publishing Company, Amsterdam, 250-271.

Rossi-Landi, Feruccio (1981) Jezik kao rad i kao tržište, Rad, Beograd.

Saussure, Ferdinand de. (2000) Tečaj opće lingvistike, Institut za hrvatski jezik i jezikoslovlje, Zagreb.

18 „Moj jezik” i „moj svijet” ovdje ne bi trebali imati odrednice partikularnosti, bilo čisto osobne ili identitetske, nego bi trebali biti univerzalno određeni. 
Wittgenstein, Ludwig (1998) Filozofijska istraživanja, Nakladni zavod Globus, Zagreb.

Wittgenstein, Ludwig (1987) Tractatus logico-philosophicus, Veselin Masleša, Sarajevo.

\section{SUMMARY \\ Karlo Jurak \\ THE PROBLEM OF THE CONSTITUTION OF THE SPEAKING SUBJECT AND THE POSSIBILITY OF METALINGUISTICS}

The problem of the relationship between the linguistic structure and the speaking subject is present in almost all linguistic theories, even those that were postulated prior to that of Ferdinand de Saussure who developed the said dichotomy to its fullest. Other dichotomies such as "function-form" and "language-thought" follow this central dichotomy. In this sense, the problem of this relationship is present in every linguistic theory before and after Saussure, at least implicitly. In order to overcome this problem, in this paper we examine the constitution of the speaking subject outside of the fixed dichotomies. Instead, we use the concepts of language management, metalanguage and metalingual ability. This calls for some hypotheses about language activity awareness, its inherently metalinguistic character and the possibility of the constitution of the speaking actor's subjectivity through reflexivity and dialogicality. For this purpose, the speaking subject, with its specific problems, is viewed through three different prisms: the philosophical, the political and the pragmatic one. The main characteristic of the philosophical dimension is the ontological and epistemological foundation of linguistic phenomena and the relationship between language and thought; the political dimension deals with the questions of power and hegemony; the pragmatic dimension emphasizes the breakdown of the dichotomy between descriptiveness and performativity as different linguistic functions. Finally, the goal of the paper is to establish universal metalinguistics, relying on the abovementioned hypotheses, while remaining within the immanent frameworks, i.e. within the framework of language itself.

Keywords: speaking subject; linguistic structure; language management; metalanguage; metalingual ability; metalinguistics 